研究論文

\title{
脳卒中片麻痺患者の歩行能力と重心動摇, 重心移動域との関連性
}

\author{
The Relationship of Walking Performance to Postural Sway and Area of Weight \\ Shifts in Patients with Hemiplegia from Cerebrovascular Accident
}

\begin{abstract}
望月久
HISASHI MOCHIZUKI

Department of Rehabilitation, Tokyo Metropolitan Ebara Hospital: 4-5-10 Higashi-Yukigaya, Ohta-ku, Tokyo 145-0065, Japan. TEL +81 3-5734-7060

Rigakuryoho Kagaku 13(1): 7-10, 1998. Submitted Dec. 3, 1996. Accepted Jan. 20, 1997.
\end{abstract}

\begin{abstract}
To examine the features of balance performance in subjects with hemiplegia, we measured the area of postural sway and the area of weight shifts in 31 patients with cerebro-vascular accident. As a result, we found a significant relationship between walking perfomance and the area of weight shifts, which suggested the ability to perform active weight shifts is important to improve walking performance of hemiplegic subjects.
\end{abstract}

Key words: hemiplegia, walking performance, suggested postural sway

要旨: 脳卒中片麻瘇患者のバランス機能の特徵を検討するために, 脳卒中片麻㾝患者 31 名を対象に患者の歩 行能力別に重心動摇面積および前後·左右方向への重心移動域を測定した。歩行能力は装具使用可, 杖使用不 可の条件で, 屋外独歩レベル, 屋内独歩レベル, 屋内監視レベル, 歩行不能レベルの4段階に分けた。測定は 足底内側を平行に $12 \mathrm{~cm}$ 離した支持基底面で行なった。重心動摇面積は 20 秒間立位保持をした時の前後左右 の重心動摇の最大值を乗じて求めた。重心移動域は患者に同じ支持基底面で前後左右に随意的に重心移動を 行なわせ, その移動幅の最大值を使用した。歩行能力レベル別に重心動摇面積, 重心移動域を比較した結果, 重心移動域と歩行能力との間に統計的有意性を認めた。特に, 歩行不能レベルと屋内監視歩行レベルの間に, 麻痺側への重心負荷率の大きな差がみられ, これは歩行可能時期の麻瘏側方向への重心移動訓練の重要性を 示唆する結果と考えた。

キーワード : 片麻㾇, 歩行能力, 重心動摇

東京都立荏原病院リハビリテーション科：東京都大田区東雪谷 4-5-10（₹ 145-0065）TEL 03-5734-7060

受付日 1996年12月3日 受理日 1997年1月20日 


\section{I.はじめに}

バランス機能の序列として, (1)一定の支持基底面にお ける姿勢保持 $\rightarrow$ (2)同じ支持基底面内での重心移動 $\rightarrow$ (3)支 持基底面が変化する中での重心移動(移動動作) がある1)。 バランス機能を支持基底面内に重心線を収める身体機能 と解釈すると，(1)の姿勢保持は重心線のゆらき（重心動 摇）が支持基底面内にあることを意味し，支持基底面を 固定した場合は重心動摇の大きさが重要な評価要素とな る。同様に(2)の重心移動では一定の支持基底面内で重心 を随意的に移動できる範囲である重心移動域が評価の要 素として重要になる。(3)の移動動作については新たに支 持基底面を作りつつ，1つの支持基底面から重心線を逸 脱させ，次の支持基底面に収めていくという，より動的 な身体制御能が要求される。これらのバランス機能の序 列は相互に関連しながら，身体運動の枠組みを提供して いると考えられる2)。

これまで私達は失調症患者を主な対象に, 歩行能力と

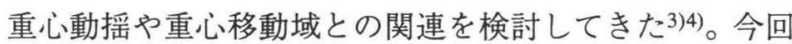
は脳卒中片麻痷患者のバランス機能の特徴を検討するた めに, 脳卒中片麻痺患者の歩行能力別に重心動摇および 重心移動域の測定を行った。その結果, 歩行能力との関 連性および失調症患者との対比において若干の知見を得 たので報告する。

\section{II. 対 象}

対象は験者の指示が理解できる脳卒中片麻瘏患者 31 名 (男: 20 名, 女： 11 名, 平均年齢: $63.8 \pm 9.5$ 歳) とし た。歩行能力は下肢装具の使用は認めるが杖を使用しな い条件で, A：運動療法室外の屋外歩行スペースを 1 人で 歩行できる (屋外独歩レベル：8名), B：運動療法室内は
1 人で歩行できる（屋内独歩レベル：7名）, C：運動療法 室内でも監視が必要 (屋内監視レベル:9名), D: $10 \mathrm{~m}$ 以 上歩行できない（歩行不能レベル：7名）の4段階に分け た。対象者の詳細は表 1 に示した。

\section{III. 方 法}

重心動摇，重心移動域の測定は，チャテックス社製の バランス評価システムを使用した。足圧測定用のセン サー台を $12 \mathrm{~cm}$ 離して平行に配置し, 被験者に足底内側 が $12 \mathrm{~cm}$ 離れるような立位をとらせた。被験者には歩行 能力レベルと対応させるため下肢装具の使用は認めた。 この支持基底面にて重心動摇と重心移動域を測定した。 重心動摇の指標として, 初期の大きな身体動摇が安定し た後の 20 秒間の重心動摇の前後・左右径を乗じた重心動 摇面積を用いた。

重心移動域は重心動摇測定と同一の支持基底面で, 被 験者に前後・左右へのゆっくりとした重心移動を行なわ せた。指標としては, 重心移動域の前後·左右径の最大 值およびそれらを乗じた重心移動域面積を用いた。重心 移動域の測定に際しては, 測定前に被験者にモニター画 面を見せながら重心移動方向を確認させ，測定時にはモ ニターを見せないで重心移動を行なわせた。測定は重心 動摇, 重心移動域とも原則として2回行い, 重心動摇は 最小値, 重心移動域は最大值を用いて検討した。

また, 麻瘏側への重心移動能力の指標として, 麻瘏側 重心移動域の非麻瘏側重心移動域に対する比率（以下, 重心負荷率＝麻痺側重心移動域／非麻痺側重心移動域) を求めた。さらに失調症患者との比較をするためにバラ ンス・インデックス (Balance Index, B.I. $=\log [$ 重心移動 域面積 /重心動摇面積]) を算出し, 検討を加えた。統計 処理は一元配置分散分析を用いた。

表 1 対象者

\begin{tabular}{cccccc}
\hline 歩行能力 & 全対象者 & 屋外独歩 & 屋内独歩 & 屋内監視 & 歩行不能 \\
\hline 対象者数 (人) & 31 & 8 & 7 & 9 & 7 \\
男 (人) & 20 & 5 & 6 & 4 & 5 \\
女 (人) & 11 & 3 & 1 & 5 & 2 \\
ステージ中央値 & $\mathrm{IV}$ & $\mathrm{V} \sim \mathrm{VI}$ & $\mathrm{V}$ & II & III \\
ステージ範囲 & $\mathrm{II} \sim \mathrm{VI}$ & $\mathrm{IV} \sim \mathrm{VI}$ & $\mathrm{IV} \sim \mathrm{VI}$ & $\mathrm{III} \sim \mathrm{VI}$ & $\mathrm{II} \sim \mathrm{VI}$ \\
\hline
\end{tabular}

全平均年齢 $63.8 \pm 9.5$ 歳

診断 脳梗塞: 18 人, 脳出血: 13 人

麻瘏側右片麻痺: 17 人, 左片麻痺 $: 14$ 人 


\section{IV. 結 果}

片麻痺患者の重心動摇面積は歩行能力が上がるにつれ て減少傾向を示したが, 統計的有意性は認められなかっ た。重心移動域は, 左右方向, 前後方向, 面積とも歩行能 カレベルが上がるにつれて拡大し，危険率 $1 \%$ 未満で統 計的有意性を認めた（表 2)。

重心負荷率は各群とも 1 未満で, 麻瘏側への重心移動 能力の低下を認めた（表 2)。また, 重心負荷率は歩行能 カレベルが上がるにつれ増加し, 特に歩行不能群から歩 行監視群の間で大きく変化した（図 1)。

バランス・インデックスは, 歩行能力が上がるにつれ 増加し, 危険率 $1 \%$ 末満で統計的有意性を認めた（表2）。

\section{V. 考 察}

脳卒中片麻瘦患者の歩行能力別に立位姿勢での重心動 摇, 重心移動域を測定した結果, 片麻㽻患者の麻㽻側方 向への重心移動能力は非麻瘦側方向に較べて低く, 歩行 能力は重心移動域の増大に強く関連することが示され た。これは，これまでの報告5)-7)と一致している。さらに 歩行が可能になる段階で, 麻瘏側方向への重心移動域の 大きな拡大を認めた。これらのことは歩行能力の改善に は，まず麻㿎側への重心移動能力の改善が必要であるこ と, そして歩行の安定化には前後・左右方向への重心移 動域の拡大が必要なことを示唆している。

歩行可能時に麻㾝側の重心負荷率が急激に増加するこ とは, 片麻㾇患者の歩行訓練開始の準備段階として, 麻 㽻側へ体重負荷訓練の重要性を示している。このことは, 冒頭で述べたバランス機能の序列とも対応している。
バランス・インデックスも片麻疩患者の歩行能力と強 い関連を示した。過去の失調症患者を対象としたバラン ス・インデックスの測定 (足底内側を $10 \mathrm{~cm}$ 離した支持 基底面で 30 秒間の重心動摇面積と重心移動域面積から 算出) では, 平地歩行安定群: $1.65 \pm 0.15$, 平地歩行不安 定群: $1.33 \pm 0.24$, 歩行不能群 : $0.96 \pm 0.25$ であった。測 定条件はやや異なるが, 失調症患者の平地歩行安定群を 今回の屋外・屋内独歩群 (バランス・インデックス: 1.86 $\pm 0.23,1.75 \pm 0.22)$, 歩行不安定群を屋内監視歩行群 $(1.35 \pm 0.25)$, 歩行不能群を片麻盘患者の歩行不能群

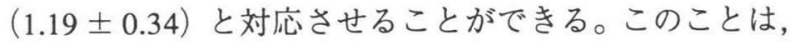
脳卒中片麻痷患者においては麻疸側への重心移動域がバ ランス能力の重要な要素となるが, 総じたバランス能力 の指標としては, 重心動摇と重心移動域の相対関係から 求めるバランス・インデックスが有効であることを示唆 していると考える。

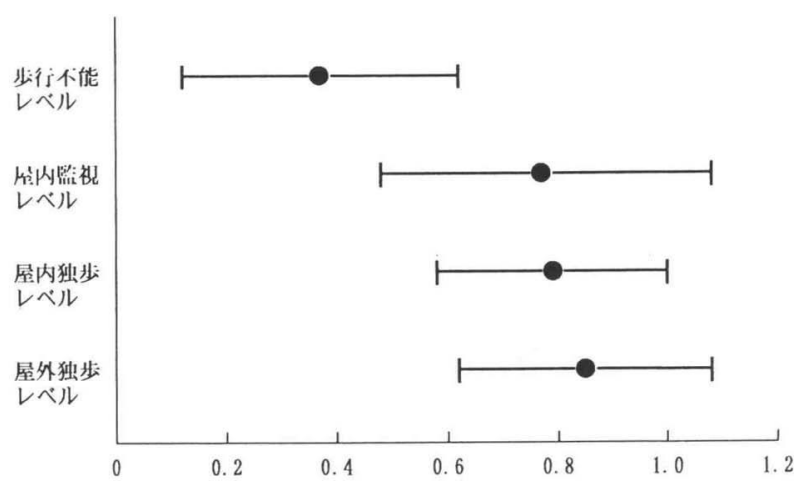

図1 重心負荷率の歩行能力による変化

注）重心負荷率＝麻瘏側重心移動域／非麻痷側重心移動域

表 2 歩行能力別の重心動摇面積, 重心移動域, 重心負荷率, バランス・インデックス

\begin{tabular}{|c|c|c|c|c|c|c|}
\hline 歩行能力 & $\begin{array}{c}\text { 重心動摇面積 } \\
\left(\mathrm{cm}^{2}\right)\end{array}$ & $\begin{array}{c}\text { 左右方向の重心 } \\
\text { 移動域 }(\mathrm{cm})\end{array}$ & $\begin{array}{c}\text { 前後方向の重心 } \\
\text { 移動域 }(\mathrm{cm})\end{array}$ & $\begin{array}{l}\text { 重心移動域 } \\
\text { 面積 }\left(\mathrm{cm}^{2}\right)\end{array}$ & 重心負荷率 & $\begin{array}{l}\text { バランス· } \\
\text { インデックス }\end{array}$ \\
\hline 屋外独歩 & $3.2 \pm 1.2$ & $18.7 \pm 1.3$ & $11.7 \pm 1.6$ & $219.7 \pm 41.3$ & $0.86 \pm 0.23$ & $1.86 \pm 0.23$ \\
\hline 屋内独歩 & $3.1 \pm 1.2$ & $17.2 \pm 2.0$ & $9.5 \pm 0.8$ & $162.7 \pm 24.6$ & $0.78 \pm 0.22$ & $1.75 \pm 0.22$ \\
\hline 屋内監視 & $6.3 \pm 4.0$ & $14.2 \pm 2.9$ & $8.4 \pm 2.3$ & $123.2 \pm 42.7$ & $0.76 \pm 0.34$ & $1.35 \pm 0.25$ \\
\hline 歩行不能 & $7.7 \pm 7.5$ & $12.1 \pm 3.6$ & $7.2 \pm 2.0$ & $92.8 \pm 48.1$ & $0.36 \pm 0.25$ & $1.19 \pm 0.34$ \\
\hline F值 & 1.851 & $8.241 * *$ & $7.631 * *$ & $13.27 * *$ & $4.813 * *$ & $9.720 * *$ \\
\hline
\end{tabular}

注 1) 重心負荷率=麻痺側重心移動域 /非麻痺側重心移動域

注 2) バランス・インデックス $=\log ($ 重心移動域面積 $/$ 重心動摇面積）

注 3）**：一元配置分散分析により，歩行能力を要因として水準間に危険率 $1 \%$ 未満で有意差あり。

$[\mathrm{F}(3,27,0.05)=2.961, \mathrm{~F}(3,27,0.01)=4.601]$ 


\section{文 献}

1) 星 文彦: 失調症に対する理学療法. 理学療法, 5:109-117, 1988.

2) 望月 久:神経疾患と姿勢調節. 理学療法ジャーナル, 30(5): 311-315, 1996.

3) 望月 久·他: 春䯣小脳変性症患者の歩行能力と重心動摇. 運動生理, 5(1): 9-14, 1990.
4) 望月 久.他：B.I. (Balance Index) と起立検査の関連性. 理 学療法学, 22(Supplement): 342, 1995.

5) Turnbull GI, et al.: Deficiencies in standing weight shifts by ambulant hemiplegic subjects. Arch Phys Med Rehabil, 77: 356$362,1996$.

6) 堀 秀明・他: 片麻瘒患者における最大重心移動距離. 理学 療法学, 20(4):261-264, 1993.

7) 菅原憲一·他:片麻痷患者の歩行能力と麻瘏側機能との関係. 理学療法学, 20(5):289-293, 1993. 